\author{
Ksenia Gałuskina
}

University of Silesia

Joanna Sycz

University of Silesia

\title{
LATIN MAXIMS AND PHRASES IN THE POLISH, ENGLISH AND FRENCH LEGAL SYSTEMS - THE COMPARATIVE STUDY ${ }^{1}$
}

\begin{abstract}
The aim of this research paper is to examine Latin in the context of legal translation between the Polish, English and French languages. Latin appears in contemporary legal discourse in the form of maxims, short phrases and terms. Even though it constitutes an integral element of legal drafting, Latin often attracts little attention from legal translators. It is falsely assumed that Latin elements of the text do not require translation due to several misconceptions related to the Latin language. Firstly, Latin is generally perceived as a global language with no local variations in form. Secondly, Latin is believed to be the universal point of reference in international communication (which is true only in the case of the natural sciences). Thirdly, Latin legal phrases or maxims are thought to originate solely from Roman law, thus they express only Roman legal thought.

In the first part of the paper we will address the above issues. To this end, we will briefly discuss the historical presence of Latin in the European linguistic context. We will then present the results of our research into the use of Latinisms in the Polish, French and English legal systems. The subject of our research was a set of twenty Latin maxims and phrases that frequently appear in the decisions of the Polish courts. During the first stage of the analysis, the items in question were verified in Legalis (the on-line service devoted to Polish law). The second stage of the research involved the consultation of monolingual dictionaries of French and English legal language to verify the universal character of the analyzed Latinisms. During the third stage of the analysis, we looked at the practical use of Latinisms in online databases of legal texts (Dalloz.fr, Westlaw International). The paper concludes with some comments on Latinisms in lexicographical publications and online sources.
\end{abstract}

Keywords: legal Latin, legal maxims, Latinisms, legal translation

Even though Latin constitutes an important element of the cultural heritage of Europe, it has almost disappeared from the linguistic arena and apart from several cliché expressions, is generally unknown to the average European citizen. One of the few domains where it has remained in use is 
in law. There are still many legal practitioners who use Latin to a wide extent in legal drafting and speech, believing that the language adds authority and prestige to their words. Latin appears in contemporary legal discourse only occasionally (its intensity varies from one language to another) in the form of maxims, short phrases or terms, yet when it does - it constitutes a potential pitfall for the translator. Due to several common overgeneralisations it is falsely assumed that the Latin elements of the text do not require translation.

Firstly, Latin is generally perceived as a universal language with no local variations in form. Indeed, in the Middle Ages, Latin gained the status of a lingua franca on the European continent. However, as the result of interaction with local languages, the form of Latin has altered in various parts of Europe.

Secondly, Latin is believed to be a universal point of reference in contemporary professional communication, which holds true, but only in the case of the natural sciences. Latin nomenclature is uniformly applied and understood by specialists working in fields such as medicine, pharmacy or biology. The same cannot be said of legal Latin, because of the culturedependent character of law itself. As Šarčević (2000:231) put it:

Unlike medicine, chemistry, computer science and other disciplines of the exact sciences, law remains first and foremost a national phenomenon. Each national or municipal law, as it is called, constitutes an independent legal system with its own terminological apparatus and underlying conceptual structure, its own rules of classification, sources of law.

The third source of potential confusion is the misconception that Latin legal phrases and maxims originated solely from Roman law, and thus express Roman legal thought. This is only partially true, as will be explained further on in the text.

There exists a vast literature on the topic of legal Latin and its history (an interesting discussion can be found in Tiersma, 2000; Matulewska, 2003; Mattila, 2006). However, there is still a scarcity of comparative studies that would show the scale of discrepancies in specific linguistic contexts. This study is an attempt to enrich existing knowledge with information on Polish, English and French legal Latin.

To properly understand the nature of Latinisms appearing in modern legal writing, one needs to look at the historical presence of Latin and Roman law on the European continent. This issue will be addressed in the first part of the paper. We will then present the results of a comparative study into the use of Latin in Polish, French and English contemporary legal discourse. 
In the concluding part of the discussion, some comments on Latinisms in lexicographical publications and online sources will be provided.

\section{The Roman legacy in European law}

The Latin language was originally used by Romans, who during their extensive military campaign managed to gain control over vast territories of contemporary Western Europe. The Roman legacy, however, was not absorbed by the European continent in the heyday of Roman domination, but five centuries after the fall of the Empire. In the $11^{\text {th }}$ century the texts of ancient Roman law were rediscovered. It was a time of significant political, economic and cultural transformation in Europe, instigated by the sudden embrace of Roman heritage (Stein, 1999).

It should be stressed here that the very term Roman law can be understood in two ways. In its wider sense, it covers the entire legal legacy developed in all epochs of the Roman Empire, from the Twelve Tables (dated $450 \mathrm{BC}$ ) to Justinian's Compilation (534 AD). In its narrow and more common meaning, Roman law denotes only Justinian's Compilation (also known under the name of the Corpus Juris Civilis). It is a compilation of Roman legal texts, assembled after the fall of Rome, on the initiative of Justinian, the emperor of the Eastern Empire, in order to preserve and revive the best of Roman law from all former epochs. Its most influential part, the Digest, was the collection of citations extracted from the most valuable Roman legal writings. In this paper, Roman law is understood as the Corpus Juris Civilis.

Roman law was first studied at the University of Bologna - the first university in Europe, founded in $1088 \mathrm{AD}$ with the aim of studying the Corpus Juris Civilis (Glendon, Carozza \& Picker, 2007). Roman legal thought was then gradually disseminated across Europe via newly-established universities. It reached first the academia and then the practitioners of law, who were often recruited among university graduates. This is how Wolff (1951:193) describes this process:

The reception was not planned and was nowhere complete. It was a complex process of gradual infiltration through the action of university trained judges, lawyers, and draftsmen of legal documents; through opinions based on Roman law, rendered by professors of Roman law for the use of judges or parties in specific lawsuits; and through the work of learned men who undertook to draft statutes or to compile comprehensive statements of legal principles for the use of judges and attorneys. 
Roman civil law, together with the immense literature devoted to this topic, soon formed the jus commune ${ }^{2}$, i.e., the common legal system of Europe, applied in most western countries until the end of the $18^{\text {th }}$ century (Wolff, 1951). The jus commune did not substitute, but interacted with other widespread bodies of law, like canon law or merchant law, as well as local customary and feudal laws (Glendon, Carozza \& Picker, 2007).

Reception of the jus commune took different forms across Europe (Wolff, 1951). It was especially intensive in the territory of contemporary Germany, where it prevailed until the $19^{\text {th }}$ century. Poland, on the other hand, strongly resisted the introduction of the jus commune, mostly for political reasons, i.e., difficult relations with the Holy Roman Empire, which was perceived as the heir of the Roman legacy (Jońca, 2009). The differences in absorption of Roman legal ideas could be seen even within one country, i.e. in France, divided into pays de droit écrit (land of written law) in the more Romanized south, and pays de droit coutumier (land of customary law) in the north (Janin, 2009). The jus commune never played a major role in the English legal system, though it was well-known in legal circles. The main motivation for the introduction of the jus commune on the continent was the growing need for a common legal system. The British lands, however, had developed their own legal concepts (common law and equity law) before the jus commune was established in mainland Europe. As Wolff (1951:198) explains:

... the early establishment of a well-ordered system of royal courts under Henry II (1154-89) made possible the beginning of a unification and, soon, comprehensive statements of the national law.... This, combined with the rise of a legal profession trained in the national law and proud of it, gave sufficient strength to English law to withstand the intrusion of Roman ideas.

Nonetheless, English legal draftsmen allowed the introduction of some Roman legal solutions into English law, as long as they did not interfere with the foundations of the English legal system (Wolff, 1951).

The prevalence of the jus commune came to an end at the time of codification of national laws. The most influential codes were the French Civil Code (1804, also called the Code of Napoleon) and the German Civil Code (1896). Both codes drew on the jus commune, thus they preserved some Roman rules and institutions until modern times. The French Civil Code came into force in the territory of Poland in 1808 (Wołodkiewicz, 2008). It was the first large-scale reception of Roman law in Poland (Litewski, 1995). 


\section{Latin in European legal discourse: a historical overview}

Latin did not fade into oblivion after the collapse of Imprerium Romanum (476 AD). The language was preserved on the European continent by the Catholic Church, which established Latin as its official language and incorporated many Roman legal concepts into canon law (Jońca, 2009). In the hands of the Church, Latin was brought to the most distant areas of the European continent (stretching from Ireland to Poland and from Sicily to Scandinavia). At first, Latin was the language of liturgy. However, its presence soon extended to other fields, such as law, administration, education and the arts (Farrell, 2001). It was the language of official documents, judicial proceedings, correspondence, diplomacy, etc. Even though Latin prevailed among the educated elite, it never superseded local languages, rather it coexisted with them, in a different manner in each particular country. In Poland, in the times of the Polish First Republic, Latin had the status of one of the official languages, and was spoken and understood not only among the aristocracy, but also the poor nobility (Jońca 2009; Szczepankowska, 2007). However, with the development of national languages, Latin gradually lost its position. In France, the use of Latin in official documents was abolished in 1539, upon the decision of Francis I of France (Ordinance of VillersCotterêts). In Poland, Latin was officially used until 1795, i.e., the third partition of Poland.

As regards the British lands, during Roman domination Latin could be heard only among Romans and disappeared from the isles together with the conquerors in the $5^{\text {th }}$ century (Tiersma, 2000). The language appeared again in these territories in $597 \mathrm{AD}$, brought by Catholic missionaries, but never enjoyed a position comparable to that in continental Europe. Shortly after conquering England (1066 AD), the Normans introduced French as the language of official communication. For several centuries that followed, English, Latin and French existed side-by-side forming a truly peculiar linguistic reality. English was the language of commonalty and oral communication, while French and Latin were the languages of the educated elite and written record. All three languages were also used in the legal context. As Tiersma (2000:34) explains:

Many written pleadings and legal records were in Latin. Speech directed at nonlawyers - such as discussions with clients or questioning of witnesses in court - would necessarily have been in English. And interchanges with other barristers or judges in court - especially oral pleading - would have been in French... 
Use of conjoined phrases, still popular in legal writing, e.g., deem and consider, fit and proper, will and testament, dates back to this particular time. The English Parliament finally proscribed the use of Latin in legal proceedings in 1731 (Plucknett, 1956 quoted in Tiersma, 2000). It soon turned out, however, that Latin could not be completely erased from legal writing. Many legal concepts expressed in Latin had no counterparts in the English language. This is one of the reasons why many Latinisms, e.g., fieri facias, habeas corpus, ne exeat, nisi prius, remained in use until modern times (Garner, 2001).

\section{Latin in the modern era}

The role of Latin significantly diminished after the emancipation of national languages (Tiersma, 2006), yet it has never vanished from the European linguistic landscape. Latin is still taught at universities, especially departments of linguistics and law faculties, as well as selected high schools, in order to preserve the legacy of Antiquity. It should be noted, however, that the presence of Latin in formal education differs from one country to another, which has a direct effect on the amount of Latinisms in professional communication.

Today, Latin is constantly being attacked by the supporters of the plain language movement, who argue that abuse of Latinisms in legal writing impedes communication and discriminates in favour of those in the know (Garner, 2001; Eacina na tawie oskarżonych, 2004). Yet, despite widespread criticism, legal maxims and phrases are still used by many law practitioners as a handy tool in their legal rhetoric, mostly because of the aura of splendour and erudition surrounding the language (Tiersma, 2000). Latin maxims are also referred to during the construction of new legal solutions, as a source of ever-lasting legal wisdom (Jońca, 2009), even though they themselves do not constitute binding legal rules.

In the legal context, Latin survived in the form of maxims, phrases or terms of art, scattered over the texts written in national languages. Maxims can be defined as independent sentences that express traditional legal principles, e.g., English ignorantia juris neminem excusat. Phrases are shorter in form than maxims; many of them have a native language equivalent, thus they serve mostly stylistic function, e.g., sensu stricto, ad hoc, a contrario, a priori, de facto, and can also be spotted in non-legal texts. As Garner (2001) pointed out, some Latin phrases have become such standard elements of legal writing that their presence is unobjectionable, e.g., versus, 
bona fide. Latin terms of art convey precise legal meaning that could not be expressed otherwise in some national languages, e.g., English prima facie, ex parte, quorum, subpoena (Garner, 2001) or French intuitus personae, accipiens, solvens.

Due to the fact that Latin was the language of the Corpus Juris Civilis, which is perceived as the common foundation of continental legal systems, there is a tendency to think that all contemporary Latinisms originated directly from this particular source, and therefore must be universal. In fact, the Latin language outlived the Roman Empire by well over a thousand years, and was also applied in the formation of legal principles of national character. As a consequence, in contemporary legal discourse we can find Latinisms of different provenance, such as:

- Latinisms that have survived in unchanged form since Roman times, e.g., English duo non possunt in solido unam rem possidere, Polish impossibilium nulla obligatio est, or superficies solo cedit, present in Polish, English and French legal systems.

- Latinisms that were formulated in the post-Roman era, but on the basis of ancient Roman legal texts, e.g., Polish lex posterior derogat priori, nasciturus pro iam nato habetur quotiens de commodis eius agitur, or lex retro non agit (Litewski, 1995).

- Latinisms that come from canonical law, e.g., pacta sunt servanda, and common or equity law, e.g., volenti non fit iniuria, but are now applied in other legal systems (Jońca, 2009).

- Latinisms coined and used within national legal systems, even if they express concepts existing in other legal systems, e.g., nasciturus or culpa in contrahendo in Polish law, intuitus personae or assipiens in French law, or stare decisis or habeas corpus in common law.

\section{Methodology}

The aim of the research was to verify the universality of Polish Latinisms by comparing their use in Polish, French and English legal discourse. It was decided that the subject of the analysis should be Latin maxims and phrases that are still willingly used by Polish legal practitioners. Hence, during the selection of the research material we consulted two ranking lists assembled by Wołodkiewicz (2001). They present Latin maxims and phrases found in the decisions rendered by Polish courts, listed in order from most to least popular, together with the exact number of occurrences in the analysed corpus. 
During the first stage of the analysis the popularity of the Latinisms in question was verified in Legalis (LPL) - an online information service devoted to Polish law. The second stage of the research involved a verification process in order to establish whether Polish Latinisms also exist in French and English legal discourse. To this end, we consulted the following monolingual legal dictionaries:

- Adages du droit français (Roland \& Boyer, 1999) - RBA - the richest dictionary of French legal maxims (including maxims coined both in French and Latin);

- Locutions latines du droit français (Roland \& Boyer, 1998) - RBL - the richest dictionary of Latin phrases in French legal discourse;

- Black's Law Dictionary (Garner, 2009) - BLD - perceived as the most exhaustive lexicographic work devoted to English legal language, including also comments on foreign and historical legal concepts, e.g., civil or Roman law.

The above legal dictionaries constitute a written record of lexical items that belong to specific legal discourse. They also provide general information on the grammar, syntax and meaning of the items, but they do not account for their actual use. Therefore, during the third stage of the analysis, the Latinisms in question were verified in the following on-line legal databases:

- Dalloz.fr - DFR - a legal information service devoted to French law;

- Westlaw International UK Collection - WLI - a legal information service concerning English-speaking countries (i.e., UK, US, Australia, Hong Kong, Canada and EU); in this study only the UK legal context was taken into account.

Both DFR and WLI contain authentic legal texts, such as court decisions, statutes, sample documents and articles from law journals. Therefore, they mirror the actual use of legal terminology. Their content and form are comparable to Legalis; the three databases in question are intended for legal professionals and for informational purposes. In this study, the above mentioned legal databases serve the function of specialised comparable corpora, from which examples of the practical use of Latinisms can be extracted. This methodology corresponds to corpus-driven approaches in corpus linguistics, which rely on different kinds of authentic texts as a source of linguistic knowledge, rather than on a corpus built according to pre-existing requirements (Tongini \& Bonelli, 2010; Gałuskina, 2013a). Use of existing databases, however, does not allow extraction of exact statistical data, because of the undefined corpus size. 
Latin Maxims and Phrases in the Polish, English and French Legal Systems

\section{Research results}

A general discussion of the research results is presented below. The detailed data can be found in Appendix 1.

\section{Maxims}

The top ten maxims on the list by Wołodkiewicz (2001) were selected for the analysis; they were as follows:

1. lex retro non agit (the law is not retroactive);

2. in dubio pro reo (in a doubtful case, for the defendant);

3. nullum crimen (nulla poena) sine lege (poenali) (no punishment without a law authorizing it);

4. pacta sunt servanda (agreements must be kept);

5. superficies solo cedit (whatever is attached to the land forms part of $i t$;

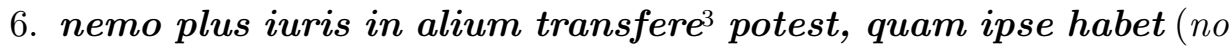
one can transfer to another a greater right that he himself has);

7. clara non sunt interpretanda (what is clear does not need interpretation);

8. ignorantia iuris nocet (ignorance of law excuses no one);

9. ne bis in idem (not twice for the same thing);

10. exceptiones non sunt extendendae (exceptions cannot be extended). The investigation of the items in the LPL produced dozens, hundreds or even several thousand results, confirming the popularity of the above phrases in Polish legal writing.

With regard to French, two out of the ten maxims - lex retro non agit and clara non sunt interpretanda - were not included in the RBA. Four maxims were present in the RBA, but in forms that are different from those used in Polish:

- nemo plus juris ad alium transferre potest quam ipse habet-instead of - nemo plus iuris in alium transferre potest, quam ipse habet,

- ignorantia legis non excusat - instead of - ignorantia iuris nocet,

- non bis in idem - instead of - ne bis in idem,

- exceptio est strictimissimae interpretationis - instead of - exceptiones non sunt extendendae.

Verification of the maxims in the DFR showed that two maxims included in the RBA do not appear or appear only once in the DFR, which suggests that in practice they are hardly ever used by legal practitioners. These are: ignorantia iuris nocet and nemo plus iuris in alium transfere potest, quam ipse habet. 
Moreover, examination of the DFR revealed several form variations of the maxims analysed. The Polish version of the maxim ne bis in idem appears in the DFR only once. The item occurs more often in the variant form non bis in idem (this form is also registered in the RBA), but only in the context of criminal law. The maxim nullum poena sine lege is also registered in the DFR in several variant forms, such as nullum crimen nulla poena sine lege and nullum crimen, nulla poena, nullum judicium sine lege. Maxims lex retro non agit and clara non sunt interpretanda are absent both in the RBA and the DFR.

As far as English is concerned, the BLD does not include four out of the ten maxims:

- lex retro non agit,

- in dubio pro reo,

- clara non sunt interpretanda,

- exceptiones non sunt extendendae.

With regard to the maxim nullum crimen (nulla poena) sine lege (poenali), the BLD includes only one variant: nulla poena sine lege. Two maxims appear in the BLD in a modified form; they are as follows:

- nemo plus juris ad alienum transferre potest quam ipse haberet - instead of - nemo plus iuris in alium transferre potest, quam ipse habet;

- ignorantia juris non excusat, ignorantia juris neminem excusat, ignorantia legis non excusat, ignorantia juris haud excusat - instead of ignorantia iuris nocet.

One of the maxims, ne bis in idem (including the variant from: non bis in idem) is registered in the BLD, but with the annotation that this is a civil law maxim expressing the same principle as the English rule against double jeopardy.

The WLI registers two of the four maxims not found in the BLD: lex retro non agit and in dubio pro reo. Lex retro non agit, however, appears in the WLI twice and in the context of Polish law (an English translation of a Polish Constitutional Court judgment and the case against Poland before the European Commission of Human Rights). The search in the WLI produced no results for one maxim - clara non sunt interpretanda, which confirms its strictly local character. The WLI registers two out of the four maxims which are not included in the BLD:

- singularia non sunt extendenda or exceptiones sunt strictissimae interpretationis - variants of the Polish maxim exceptiones non sunt extendendae;

- five variants of ignorantia iuris nocet, including one that is not registered in the BLD - ignorantia legis neminem excusat, plus all variants with juris spelled as iuris. 
- four variants of nemo plus iuris in alium transfere potest, quam ipse habet, three - not mentioned in the BLD, plus all variants with juris spelled as iuris. The interesting fact is that similar variants of the maxim appear also in Polish legal texts (found in the LPL). Form variations do not influence the meaning of the maxim, yet appear awkward to professionals from other legal communities.

\section{Phrases}

The first ten phrases on the list by Wołodkiewicz (2011; without ius as it is too ambiguous) were selected for the analysis:

1. ratio legis (the purpose of a law)

2. contra legem (against the law)

3. erga omnes (towards all)

4. res iudicata (a thing adjudicated)

5. rebus sic stantibus (matters so standing)

6. verba legis (wording of an act)

7. in personam (against a person)

8. in rem (against a thing)

9. quo ad usum (how to use the joint property)

10. ad personam (personal)

In general, most of the above phrases are present in French and English sources, albeit with several quite notable exceptions. As regards French legal discourse, four out of the ten phrases are not registered in the RBL: res judicata, verba legis, quo ad usum, ad personam. Two of them - verba legis and quo ad usum are also not included in the DFR. As for English, three phrases - verba legis, quo ad usum and ad personam - are not included either in the BLD or the WLI. Erga omnes is absent in the BLD, but it produces ample results in the WLI and forms interesting collocations (discussed below).

Since Latin phrases do not constitute independent locutions, it might be expected that they form distinct syntactic patterns in the three linguistic contexts discussed here (Gałuskina 2013b). By way of illustration, let us look at the collocations of contra legem and erga omnes extracted from Polish, French and English legal databases.

The collocations with contra legem are as follows:

- Polish (LPL): wykładnia contra legem, pogląd contra legem, interpretacja contra legem, wyniki contra legem, uznanie contra legem;

- French (DFR): interprétation contra legem, fait contra legem, lacune contra legem, pratiques contra legem, usage contra legem, traditions contra legem; 
- English (WLI): custom contra legem, contra legem interpetation, to interpret contra legem, to apply contra legem.

At first sight, contra legem (against the law) forms similar collocations in the three languages analysed, yet under closer scrutiny some discrepancies in the practical use of the phrase can be observed. The collocations in the three languages in question concern legal interpretation that is contrary to law governing a particular problematic issue. This seems to be the only acceptable use of this expression in Polish, while in French and English this phrase also forms collocations referring to unlawful customs. Moreover, in English, contra legem forms collocations with verbs, which is not acceptable in Polish or French.

Even bigger differences can be observed when we consider the Latin phrase erga omnes. The collocations with erga omnes extracted from Polish, French and English legal databases are as follows:

- Polish (LPL): skutek erga omnes, skuteczne erga omnes, skuteczność erga omnes, bezskuteczne erga omnes, obowiązywać erga omnes, wiązać erga omnes;

- French (DFR): opposable erga omnes, applicable erga omnes, effet erga omnes, qualité erga omnes, s'imposer erga omnes, valoir erga omnes;

- English (WLI): erga omnes character of a norm, obligations erga omnes, responsibility erga omnes, erga omnes nature of a norm, invocation erga omnes, claims erga omnes, erga omnes rule, erga omnes effect, erga omnes partes effect.

Erga omnes (towards all) is usually used in Polish in the context of the effectiveness of legal rights. In French and English, this use is extended to the effectiveness of legal provisions. Moreover, in English, in the context of international public law, this expression refers to the obligations and responsibilities of states. The WLI registers a collocation with the extended version of the phrase, namely erga omnes partes effect (effect towards all parties). It seems to be the combination of two contrary Latin phrases erga omnes and inter partes (between the parties), not observed in either Polish or French legal discourse.

Latin is an inflected language, thus declension should take place when Latin phrases are used in another inflected language, such as Polish. When it comes to non-inflected languages, like English and French, Latin expressions should remain in the nominative form. In practice, however, these grammatical rules are not always followed. Recently the tendency not to inflect Latinisms within Polish sentences has been observed (Gałuskina, 2013b). Moreover, in languages without declension, different inflected forms of one Latin expression represent various parts of speech. For example, in English, 
bona fide (with good faith or in good faith) is an adjective or an adverb, while bona fides (good faith) is a noun (Garner, 2009). In French, intuitus personae (personal reasons) is a noun, while intuitu personae (for personal reasons) is an adjective or an adverb (Cornu, 2004).

\section{Conclusion}

The above analysis serves mostly as an illustration of the problem of national character of legal Latin, since it was conducted on a small number of Latinisms, albeit the most popular ones. However, even this relatively small-scale research revealed significant incongruities among Latinisms in the specific context of Polish, English and French law. The research was undertaken with the assumption that some differences might occur, but the scale of the discrepancies found surpassed initial expectations. The data gathered in the research indicate that there exists no singular universallyapplied legal Latin, but rather numerous legal Latins integrated into the Polish, English and French linguistic context. Only some of the currentlyused Latinisms are actual extracts from the original Corpus Juris Civilis. Many were coined using the Latin language, but instead of relating to Roman law or a common European legal heritage, they express local legal concepts, for example clara non sunt interpretanda and lex retro non agit. Clara non sunt interpretanda was coined using the Latin language, but expresses the rule of law interpretation characteristic within the Polish legal system (Nowacki \& Tobor, 2000). Lex retro non agit - the most popular Latin maxim in Polish legal discourse - was formulated in its Latin form as late as the early $20^{\text {th }}$ century (Mattila, 2006). Even though it expresses the general legal principle of non-retroactivity of the law, existing in other legal systems, this maxim in its Latin form is familiar only to Polish legal practitioners. In France, the meaning of lex retro non agit is expressed by a different maxim: la loi ne dispose que pour l'avenir.

Moreover, throughout the centuries Latin has evolved in a separate manner in each linguistic system. Once Latinisms had become absorbed by a particular language, they were shaped by the new linguistic environment, drifting away at the same time from their common roots. As a result, today there exist numerous versions of Latin maxims, some used worldwide, while others are effective only in a limited area. Furthermore, the same Latin maxim may have several versions within one legal system. Thus, even if a Latinism exists in a target language, we can expect differences in its practical application or form. As illustrated above, Latin phrases form different 
syntactic patterns when used in different languages. The research showed that the phrases that could be used with considerable freedom in one language, formed only a few restricted collocations in another, or appeared within a more limited context.

As can be inferred from the above discussion, the odds that a Polish Latinism is non-existent or occurs in a different form in French or English are actually very high. Therefore, automatic transfer of Latinisms from the original into the target language is, to put it mildly, a fairly risky translation technique. Each Latin expression encountered in a translated text requires analysis similar to the one conducted in this paper. A dictionary is the first source consulted by most translators, yet the research should not end there. Our study revealed significant discrepancies between information provided in monolingual specialised dictionaries and specialist corpora. Moreover, it seems that most monolingual dictionaries are designed to assist reception of a text, rather than its production. They provide definitions of Latinisms, which are intended to help native speakers understand the meaning, but fail to include information on grammatical and syntactic features of the terms.

Bilingual legal dictionaries are no better. The selection of Latinisms in dictionaries appears to be subjective. Some dictionaries register almost no Latin expressions, e.g., the Polish-French legal dictionaries by Machowska (2008) and Łozińska-Małkiewicz (2000), and the Polish-English legal dictionary by Pieńkos (2002b), while others include many commonly known Latinisms, but omit those that are problematic for the translator. For example, French-Polish (Pieńkos, 2002a) and English-Polish (Jaślan \& Jaślan, 1994) legal dictionaries contain more Latinisms than the aforementioned dictionaries from Polish into English and French. They provide Polish translations of Latinisms, even though many Latin expressions appear in exactly the same Latin form also in Polish legal discourse, e.g., ad hoc, ad rem, lucrum cessans, lex commissoria and negotiorum gestio. Thus, the dictionaries fail to answer the questions of crucial importance for translators: is it possible to use the source language Latinism in an unchanged form in the target language, if not - is there a variation of a given Latinism or an equivalent Latinism in the target language. Moreover, bilingual dictionaries seem not to distinguish between Latinisms that belong to different languages. As a result, in the dictionaries by Jaślan \& Jaślan (1994) and Pieńkos (2002a) one can find Polish Latinisms among English or French entries, e.g., ignorantia juris nocet and nemo plus juris ad alienum transferre potest quam ipse haberet.

As of today, there exists no lexicographical work that can provide a translator with the up-to-date and comprehensive information necessary 
to make an informed decision on how to translate a given Latinism. The research in the corpus of legal texts may be more time-consuming, but gives a much broader picture. Considering the scale of discrepancies in the application of Latin in Polish, French and English legal discourse, such in-depth investigation should not be perceived as an option, but a necessity.

\section{N O T E S}

1. The paper is an outcome of the project financed by the National Science Centre in Poland.

2. The Latin sound [j] is spelled differently in the three languages analysed here. Polish orthography accepts only version ius commune, French - jus commune, while in English both versions are acceptable.

3. There is no spelling mistake here; in Polish this maxim is traditionally spelled with or without a second letter ' $r$ '.

\section{R E F E R E N C E S}

Cornu, G. (2004). Vocabulaire juridique. Paris: PUF.

Farrell, J. (2001). Latin Language and Latin Culture: From Ancient to Modern Times. Cambridge: Cambridge University Press.

Gałuskina, K. (2013a). Korpusy w pracy tłumacza. In T. Piotrowski \& Ł. Grabowski (Eds.), The Translator and the Computer (Proceedings of a Conference held in Wroctaw, April 20-21, 2012, organized by the Philological School of Higher Education and CEBM Localization Centre) (pp. 73-88). Wrocław: Wydawnictwo Wyższej Szkoły Filologicznej we Wrocławiu. Retrieved October 30, 2013, from http://www.wsf.edu.pl/upload_module/wysiwyg/ Wydawnictwo\%20WSF//The\%20Translator\%20and\%20the\%20Computer_ Piotrowski_Grabowski.pdf.

Gałuskina, K. (2013b). Le latin juridique à l'épreuve de la traduction. In B. Lewandowska-Tomaszczyk \& M. Thelen (Eds.), Translation and Meaning, Part 10 (Proceedings of the Eódź Session of the $5^{\text {th }}$ International Maastricht-Lódź Duo Colloquium on "Translation and Meaning", held in tódź, Poland, 1619 September 2010) (pp. 291-298). Maastricht: Maastricht School of Translation and Interpreting Zuyd University of Applied Sciences.

Garner, B. A. (2001). A Dictionary of Modern Legal Usage. Oxford: Oxford University Press.

Garner, B. A. (Ed. in chief). (2009). Black's Law Dictionary. Standard Ninth Edition. St. Paul: West Publishing.

Glendon, M. A., Carozza, P. G. \& Picker, C. B. (2007). Comparative Legal Traditions: Text, Materials and Cases on Western Law. $3^{\text {rd }}$ ed. St. Paul: West Publishing. 
Ksenia Gałuskina and Joanna Sycz

Janin, H. (2009). Medieval Justice: Cases and Laws in France, England and Germany, 500-1500. Jefferson: McFarland.

Jaślan, J. \& Jaślan, H. (1994). Stownik terminologii prawniczej i ekonomicznej angielsko-polski. Warszawa: Wiedza Powszechna.

Jońca, M. (2009). Krótka historia kariery łacińskich paremii w prawie. Monitor Prawniczy, 4, 182-192.

Eacina na tawie oskarżonych: druk z okazji Setnego Zjazdu Polskiego Towarzystwa Filologicznego. (2004). Warszawa: Wydawnictwo DiG.

Litewski, W. (1995). Rzymskie prawo prywatne. Warszawa: Wydawnictwa Prawnicze PWN.

Łozińska-Małkiewicz, E., (2000). Polsko-francuski słownik terminologii prawniczej. Toruń: Wydawnictwo Ewa.

Machowska, A. (2008). Stownik terminologii prawniczej polsko-francuski. Warszawa: Wolters Kluwer.

Mattila, H. E. S. (2006). Comparative Legal Linguistics. Aldershot: Ashgate.

Matulewska, A. (2003). Latin Maxims and Expressions in English, Estonian and Polish Legal Language in the Aspect of Translation. Investigationes Lingvisticae, 10. Retrieved February 26, 2013, from: http://www.staff.amu.edu.pl/ $\sim$ inveling $/$ /index.php? page $=$ issuesandvol $=10$ andcat $=0$ andarticle $=15$.

Nowacki, J. \& Tobor Z. (2000). Wstęp do prawoznawstwa. Kraków: Zakamycze.

Pieńkos, J. (2002a). Francusko-polski leksykon. Prawo. Handel. Ekonomia. Kraków: Zakamycze.

Pieńkos, J. (2002b). Polsko-angielski stownik prawniczy. Kraków: Zakamycze.

Plucknett, T. F. T. (1956). A Concise History of the Common Law. Boston: Little, Brown and Co.

Roland, H. \& Boyer, L. (1998). Locutions latines du droit français. Paris: Litec.

Roland, H. \& Boyer, L. (1999). Adages du droit français. Paris: Litec.

Šarčević, S. (2000). New Approach to Legal Translation. Hague: Kluwer Law International.

Stein, P. (1999). Roman Law in European History. Cambridge: Cambridge University Press.

Szczepankowska, I. (2007). Polszczyzna w komunikacji prawno-sadowej dawnej Rzeczypospolitej. Retrieved February 26, 2013, from: http://www.rjp.pan.pl/ index.php?option $=$ com_contentandview $=$ articleandid $=1377$ andItemid $=50$.

Tiersma, P. M. (2000). Legal Language. Chicago, London: University of Chicago Press.

Tiersma, P. M. (2006). Some Myths About Legal Language. Law, Culture and the Humanities, 2, 29-50.

Tognini Bonelli, E. (2010). Theoretical overview of the evolution of corpus linguistics. In A. O'Keeffe \& M. McCarthy (Eds.), The Routledge handbook of corpus linguistics (pp. 14-27). London: Routledge. 
Wolff, H. J. (1951). Roman Law: An Historical Introduction. Oklahoma: University of Oklahoma Press.

Wołodkiewicz, W. (2001). Łacińskie paremie prawne w orzecznictwie sądów polskich. In W. Wołodkiewicz \& J. Krzynówka (Eds.), Eacińskie paremie $w$ europejskiej kulturze prawnej i orzecznictwie sądów polskich (pp. 7-30). Warszawa: Liber.

Wołodkiewicz, W. (2008). 200 lat Kodeksu Napoleona w Polsce - od nienawiści do miłości. Palestra, 1-2, 141-146.

\section{Appendix 1}

\section{Detailed presentation of analysis results}

Table 1

Occurrence of analysed Latin maxims in selected sources

\begin{tabular}{|c|c|c|c|c|c|}
\hline Latin maxim & LPL & $\mathrm{RBA}$ & DFR & BLD & $\begin{array}{l}\text { WLI - UK } \\
\text { Collection }\end{array}$ \\
\hline $\begin{array}{l}\text { lex retro non } \\
\text { agit }\end{array}$ & + & - & - & - & $\begin{array}{c}+/- \\
\text { (twice) }\end{array}$ \\
\hline in dubio pro reo & + & + & + & - & + \\
\hline $\begin{array}{l}\text { nullum crimen } \\
\text { (nulla poena) } \\
\text { sine lege } \\
\text { (poenali) }\end{array}$ & $\begin{array}{l}\quad \quad+ \\
\text { variants: } \\
\text { nullum crimen, } \\
\text { nulla poena } \\
\text { sine lege; } \\
\text { nullum crimen } \\
\text { sine lege; } \\
\text { nulla poena } \\
\text { sine lege }\end{array}$ & $\begin{array}{l}\quad \quad+ \\
\text { variant: } \\
\text { nullum poena } \\
\text { sine lege }\end{array}$ & \begin{tabular}{|l|}
\multicolumn{1}{c|}{$\quad+$} \\
variants: \\
nullum crimen \\
nulla poena \\
sine lege; \\
nullum crimen, \\
nulla poena, \\
nullum judicium, \\
sine lege
\end{tabular} & $\begin{array}{l}\quad \stackrel{ }{1}+ \\
\text { variant: } \\
\text { nulla poena } \\
\text { sine lege }\end{array}$ & + \\
\hline $\begin{array}{l}\text { pacta sunt } \\
\text { servanda }\end{array}$ & + & + & + & + & + \\
\hline $\begin{array}{l}\text { superficies solo } \\
\text { cedit }\end{array}$ & + & + & + & + & $\begin{array}{c}+/- \\
\text { (three times) }\end{array}$ \\
\hline $\begin{array}{l}\text { nemo plus } \\
\text { iuris in alium } \\
\text { transfere } \\
\text { potest, quam } \\
\text { ipse habet }\end{array}$ & $\begin{array}{l}\quad+ \\
\text { other variants: } \\
\text { nemo plus iuris } \\
\text { in alium trans- } \\
\text { ferre potest } \\
\text { quam ipse habet; } \\
\text { nemo plus iuris } \\
\text { ad alium trans- } \\
\text { ferre potest } \\
\text { quam ipse habet; } \\
\text { nemo plus iuris } \\
\text { ad alium trans- } \\
\text { ferre potest, } \\
\text { quam ipse } \\
\text { haberet }\end{array}$ & $\begin{array}{l}\quad+ \\
\text { variant: } \\
\text { nemo plus juris } \\
\text { ad alium trans- } \\
\text { ferre potest } \\
\text { quam ipse habet }\end{array}$ & $\begin{array}{l}+/- \\
\text { (once) }\end{array}$ & $\begin{array}{l}\quad \quad+ \\
\text { variant: } \\
\text { nemo plus juris } \\
\text { ad alienum } \\
\text { transferre } \\
\text { potest quam ipse } \\
\text { haberet }\end{array}$ & $\begin{array}{l}\quad \quad+ \\
\text { other variants: } \\
\text { nemo plus iuris } \\
\text { ad alium trans- } \\
\text { ferre potest } \\
\text { quam ipse habet; } \\
\text { nemo plus juris } \\
\text { ad alium trans- } \\
\text { ferre potest } \\
\text { quam ipse } \\
\text { haberet; } \\
\text { nemo plus juris } \\
\text { in alium trans- } \\
\text { ferre potest } \\
\text { quam ipse habet }\end{array}$ \\
\hline $\begin{array}{l}\text { clara non sunt } \\
\text { interpretanda }\end{array}$ & + & - & - & - & - \\
\hline
\end{tabular}


Ksenia Gałuskina and Joanna Sycz

\begin{tabular}{|c|c|c|c|c|c|}
\hline Latin maxim & LPL & RBA & DFR & BLD & $\begin{array}{l}\text { WLI - UK } \\
\text { Collection }\end{array}$ \\
\hline $\begin{array}{l}\text { ignorantia iuris } \\
\text { nocet }\end{array}$ & + & $\begin{array}{l}\quad \quad+ \\
\text { variant: } \\
\text { ignorantia legis } \\
\text { non excusat }\end{array}$ & $\begin{array}{l}+/- \\
\text { (once) }\end{array}$ & $\begin{array}{l}\quad+\quad \\
\text { variants: } \\
\text { ignorantia juris } \\
\text { non excusat; } \\
\text { ignorantia juris } \\
\text { neminem } \\
\text { excusat; } \\
\text { ignorantia legis } \\
\text { non excusat; } \\
\text { ignorantia juris } \\
\text { haud excusat }\end{array}$ & $\begin{array}{l}\quad \quad+ \\
\text { variants: } \\
\text { ignorantia iuris } \\
\text { non excusat; } \\
\text { ignorantia } \\
\text { iuris neminem } \\
\text { excusat; } \\
\text { ignorantia } \\
\text { iuris haud } \\
\text { excusat; } \\
\text { ignorantia } \\
\text { juris neminem } \\
\text { excusat; } \\
\text { ignorantia legis } \\
\text { neminem } \\
\text { excusat }\end{array}$ \\
\hline ne bis in idem & + & $\begin{array}{l}\quad+ \\
\text { variant: } \\
\text { non bis in idem }\end{array}$ & $\begin{array}{c}+/- \\
\text { (once for } \\
\text { ne bis in idem, } \\
\text { several times for } \\
\text { non bis in idem) }\end{array}$ & $\begin{array}{l}\quad+ \\
\text { other variant: } \\
\text { non bis in idem }\end{array}$ & + \\
\hline $\begin{array}{l}\text { exceptiones } \\
\text { non sunt } \\
\text { extendendae }\end{array}$ & + & $\begin{array}{l}\quad+ \\
\text { variant: } \\
\text { exceptio est } \\
\text { strictimissimae } \\
\text { interpretationis }\end{array}$ & - & - & $\begin{array}{l}\quad \quad+ \\
\text { variants: } \\
\text { singularia } \\
\text { non sunt } \\
\text { extendenda; } \\
\text { exceptiones } \\
\text { sunt } \\
\text { strictissimae } \\
\text { interpretatio- } \\
\text { nis }\end{array}$ \\
\hline
\end{tabular}

Table 2

Occurrence of analysed Latin phrases in selected sources

\begin{tabular}{|c|c|c|c|c|c|}
\hline Latin phrase & LPL & $\mathrm{RBL}$ & DFR & BLD & $\begin{array}{l}\text { WLI - UK } \\
\text { Collection }\end{array}$ \\
\hline ratio legis & + & + & + & $\begin{array}{l}+ \\
\text { other variant: } \\
\text { ratio juris }\end{array}$ & + \\
\hline contra legem & + & + & + & + & + \\
\hline erga omnes & + & + & + & - & + \\
\hline res iudicata/judicata & + & - & + & + & + \\
\hline rebus sic stantibus & + & + & + & + & + \\
\hline verba legis & + & - & - & - & - \\
\hline in personam & + & + & + & + & + \\
\hline in rem & + & + & + & + & + \\
\hline quo ad usum & + & - & - & - & - \\
\hline ad personam & + & - & $\begin{array}{c}+/- \\
\text { (three times) }\end{array}$ & - & - \\
\hline
\end{tabular}

